\title{
MANAJEMEN PENYELAMATAN IBU HAMIL PASCA BENCANA
}

\author{
Ika Nuria Syafira Iswarani ${ }^{1}$, Ismatu Aghni Fatwa Izzati $^{2}$, Rusnaindah Ifta Firdausi ${ }^{3}$, Dodik Nursanto ${ }^{4}$ \\ 1,2,3,4 Universitas Muhammadiyah Surakarta \\ e-mail : -
}

\begin{abstract}
Republic Indonesia is a disaster prone area, usually the victims are women, children, and elderly. The victim which need spesial treatment is pregnant women. The purpose of this literature review is to provide knowledge to readers in helping the post-disaster pregnant women. The method that we use in is reviewing articles through Google Scholar, Pubmed, and Mendeley. Before the evacuation, triage actions need to be carried out as an effort to sort out the patient's priorities based on the urgency of the management and consideration of the resources available for the management. Pregnant women are included in the first priority group (red) which means that they need immediate and appropriate help. The most appropriate evacuation for pregnant women is a sloping position with knees folded. If there is a back injury, make an effort so that the inferior vena cava is not crushed by the uterus. Injuries that need to be watched out for are bleeding, shock, DIC, and eclampsia. Nutritional and psychological recovery of pregnant women is also very important to prevent things that are not desirable for both mother and fetus.
\end{abstract}

Keywords

: Disaster, Pregnant Women, Triage, Evacuation, Nutrition, Psychic

\begin{abstract}
Abstrak
Republik Indonesia adalah daerah rawan bencana, biasanya para korban adalah wanita, anak-anak, dan lansia. Korban yang membutuhkan perawatan khusus adalah wanita hamil. Tujuan dari tinjauan literatur ini adalah untuk memberikan pengetahuan kepada pembaca dalam membantu wanita hamil pasca bencana. Metode yang kami gunakan adalah meninjau artikel melalui Google Cendekia, Pubmed, dan Mendeley. Sebelum evakuasi, tindakan triase perlu dilakukan sebagai upaya untuk memilah prioritas pasien berdasarkan urgensi manajemen dan pertimbangan sumber daya yang tersedia untuk manajemen. Wanita hamil termasuk dalam kelompok prioritas pertama (merah) yang berarti bahwa mereka membutuhkan bantuan segera dan tepat. Evakuasi yang paling tepat untuk wanita hamil adalah posisi miring dengan lutut terlipat. Jika ada cedera punggung, usahakan agar vena cava inferior tidak dihancurkan oleh rahim. Cedera yang perlu diwaspadai adalah pendarahan, syok, DIC, dan eklampsia. Pemulihan gizi dan psikologis ibu hamil juga sangat penting untuk mencegah hal-hal yang tidak diinginkan baik untuk ibu maupun janin.
\end{abstract}

Kata kunci : : Bencana, Wanita Hamil, Triase, Evakuasi, Nutrisi, Psikis

\section{PENDAHULUAN}

Wilayah Negara Kesatuan Republik Indonesia merupakan daerah rawan bencana. Bencana di Indonesia diakibatkan oleh posisi Indonesia yang terletak di garis Katulistiwa dan berbentuk Kepulauan, fenomena perubahan iklim, letak pulaupulau di Indonesia diantara tiga lempeng tektonik dunia, dan peningkatan jumlah penduduk yang disertai dengan peletakan permukiman yang tidak terkendali dan tertata dengan baik, kesadaran masyarakat terhadap kebersihan dan keamanan yang kurang serta tingginya perkembangan teknologi. ${ }^{1}$

Dalam Undang-Undang Republik Indonesia Nomor 24 Tahun 2007 tentang Penanggulangan Bencana Pasal 26 Ayat 1a menyatakan bahwa, "Setiap orang berhak mendapatkan perlindungan sosial dan rasa aman, khususnya bagi kelompok masyarakat rentan bencana." Kelompok masyarakat rentan bencana adalah anggota masyarakat yang membutuhkan bantuan karena keadaan yang di sandangnya di 
antaranya masyarakat lanjut usia, penyandang cacat, anak-anak, serta ibu hamil dan menyusui. ${ }^{2}$

Menurut Direktur Pemberdayaan

Masyarakat Badan Nasional

Penanggulangan Bencana (BNPB), Lilik

Kurniawan mencatat 60 hingga 70 persen mayoritas korban bencana yang ada di Indonesia adalah perempuan, anak-anak dan lansia. Pada wanita hamil kebanyakan membutuhkan pertolongan untuk menyelamatkan diri. Pertolongan yang diberikan pun berbeda dari korban lainnya karena pada ibu hamil perlu memperhatikan keselamatan 2 jiwa. $^{3}$

Pengawasan paska badai Katrina di Colorado menemukan 3\% dari kunjungan ruang gawat darurat adalah masalah yang berkaitan dengan kebidanan dan 13-15\% rumah tangga pengungsi membutuhkan layanan yang terkait dengan program nutrisi tambahan khusus untuk wanita, bayi, dan anak-anak, kontrol kelahiran dan kesehatan reproduksi, dan perawatan anak. $^{4}$

Sebagian besar proyek penelitian berfokus pada dampak gempa bumi tohuku dan atau paparan kronis radioaktivitas dosis rendah pada kesehatan anak-anak dan wanita hamil, serta pada berbagai gangguan, seperti kesehatan mental dan penyakit inflamatory kronis. ${ }^{5}$

Oleh karena itu, perlu diperhatikan halhal dalam penyelamatan ibu hamil, mulai dari proses evakuasi, pemberian pertolongan pertama jika diperlukan, pemantauan gizi pasca bencana, hingga dukungan sosial serta psikologis. Hal ini perlu diketahui oleh semua orang yang menjadi penolong, baik tenaga medis atau tenaga relawan.

Dari permasalahan di atas, maka kami membuat literature review mengenai manajemen penyelamatan ibu hamil dalam bencana untuk memberikan wawasan kepada pembaca dalam pertolongan pada ibu hamil pasca bencana. Adapun metode yang kami gunakan dalam penyusunan literature review yaitu review artikel melalui google scholar, Pubmed, dan mendeley.

\section{METODE}

Metode yang digunakan dalam literature review ini yaitu review article. Dengan melakukan pengumpulan referensi sebanyak 9 jurnal dan 10 buku. Referensi tersebut didapatkan melalui google scholar, Pubmed, dan mendeley. Dengan kata kunci meliputi bencana, triage, ibu hamil, evakuasi, gizi, psikis. Data akan dipilih dan kemudian dianalisis sampai mencapai tujuan karya ini.

\section{HASIL DAN PEMBAHASAN}

Penanganan perempuan korban bencana sangat membutuhkan perlakuan khusus, dikarenakan perempuan memiliki kondisi khusus pula, termasuk pentingnya antisipasi penyediaan layanan dan memberikan penanganan khusus pada ibu hamil dan menyusui. Hal tersebut dikarenakan saat masa tanggap darurat sangat mungkin terdapat ibu hamil yang akan melahirkan dan menyusui, sebagaimana yang terjadi di pengungsian korban bencana Sulawesi Tenggara. Dua orang ibu hamil melahirkan bayi kembarnya beberapa saat dalam masa tanggap darurat. Hal tersebut menyebabkan dibutuhkan pula dokter kandungan dan bidan yang dapat membantu persalinan, serta relawan perempuan dalam jumlah yang memadai pada masa tanggap darurat. ${ }^{6}$ 
Di seluruh dunia, 15\% sampai dengan $20 \%$ ibu hamil akan mengalami komplikasi selama kehamilan atau persalinan. Sekitar lebih dari 500.000 kematian ibu terjadi setiap tahun dengan $99 \%$ nya terjadi di negaranegara berkembang. Di Indonesia, berdasarkan hasil Survei Demografi Kesehatan Indonesian 2012, Angka Kematian Ibu sebesar 359 per 100,000 kelahiran hidup. ${ }^{7}$ Kematian bayi sangat dipengaruhi oleh proses persalinan. Sekitar 130 juta bayi di dunia lahir setiap tahun dan 4 juta diantaranya meninggal dunia dalam empat minggu pertama kehidupannya (periode neonatal). Menurut Survei Demografi Kesehatan Indonesia Angka Kematian Bayi 32 per 1000 kelahiran hidup. ${ }^{8}$ Sebagian besar kematian ibu terjadi pada saat persalinan dan kematian bayi baru lahir terjadi pada saat proses persalinan dan nifas. Dari analisa penyebab kematian Ibu diperoleh bahwa 90\% kematian ibu terjadi pada saat persalinan dan segera setelah persalinan. Penyebab utama kematian ibu adalah 1) Hipertensi dalam Kehamilan (32\%), 2) Komplikasi puerperum (31\%), 3) Perdarahan (20\%), 4) Abortus (4\%), 5) Perdarahan Antepartum (3\%), 6) Partus macet/lama (1\%), 7) Kelainan amnion $(2 \%), 8$ ) lain lain (7\%). ${ }^{9}$

Angka kematian ibu di Indonesia masih tinggi. Kondisi ini akan lebih buruk bila terjadi pada kondisi bencana, karena terganggunya sistem pelayanan kesehatan. Sampai saat ini data kasus kematian ibu pada daerah bencana belum terdokumentasi, sehingga data yang digunakan sebagai rujukan adalah angka kematian ibu pada situasi normal.

Sistem perawatan kesehatan memiliki peran penting yaitu masyarakat membutuhkan intervensi darurat dan perawatan kesehatan jangka panjang.
Untuk mencegah sistem perawatan kesehatan dari kewalahan, dan untuk memberikan perawatan psikososial jangka pendek dan jangka panjang yang optimal bagi mereka yang terkena dampak, rekomendasi berikut dibuat. ${ }^{10}$

1. Merencanakan dan melatih mobilisasi sistem cepat untuk dapat dengan cepat mendiagnosis gejala kontaminasi dan memberikan perawatan.

2. Mengembangkan dan mengoordinasikan jaringan (elektronik) untuk penyebaran informasi yang cepat antara berbagai organisasi (sistem medis, responden pertama, organisasi kesehatan masyarakat, pihak berwenang, dll.).

3. Bersiaplah untuk tindakan dekontaminasi dan karantina.

4. Menerapkan sistem triase yang membantu membedakan mereka yang memiliki masalah medis dengan yang memiliki gejala karena takut terpapar. Untuk mencapai ini, sistem perawatan kesehatan mental harus bergabung dengan sistem kesehatan masyarakat dan sistem tanggap darurat.

5. Melatih tanggap psikologis setelah bencana, seperti ketakutan, kemarahan, dan gejala somatik.

6. Bersiap untuk tindak lanjut dan pendaftar, yang diperlukan dalam jangka panjang untuk mengidentifikasi mereka dengan cedera psikis seperti kerusakan akibat radiasi yang terlambat atau kanker, atau gangguan kejiwaan.

Evakuasi dan pelayanan kesehatan pada korban pasca bencana peru dilakukan tindakan triage sebagai upaya pemilahan prioritas pasien berdasarkan urgensi dilakukannya tatalaksana dan pertimbangan sumber daya yang tersedia untuk tatalaksana tersebut.11 Hal ini 
didasarkan pada prioritas ABC (Airway dengan proteksi cervical spine, Breathing, Circulation dengan kontrol perdarahan). Dalam triage perlu dilakukan pencatatan usia, tanda vital, mekanisme cedera, urutan kejadian, dan perjalanan penyakit pada fase pra Rumah Sakit. Pembagian triage sebagai berikut: ${ }^{12}$

1. Prioritas Nol (Hitam): Pasien mati atau cedera fatal yang jelas dan tidak mungkin diresusitasi.

2. Prioritas Pertama (Merah): Pasien cedera berat yang memerlukan penilaian cepat serta tindakan medik dan transport segera untuk tetap hidup (misal : gagal nafas, cedera torakoabdominal, cedera kepala atau maksilofasial berat, syok atau perdarahan berat, luka bakar berat, ibu hamil).

3. Prioritas Kedua (Kuning): Pasien memerlukan bantuan, namun dengan cedera yang kurang berat dan dipastikan tidak akan mengalami ancaman jiwa dalam waktu dekat. Pasien mungkin mengalami cedera dalam jenis cakupan yang luas (misal : cedera abdomen tanpa syok, cedera dada tanpa gangguan respirasi, fraktur mayor tanpa syok, cedera kepala atau tulang belakang leher tidak berat, serta luka bakar ringan).

4. Prioritas Ketiga (Hijau): Pasien dengan cedera minor yang tidak membutuhkan stabilisasi segera, memerlukan bantuan pertama sederhana namun memerlukan penilaian ulang berkala (cedera jaringan lunak, fraktur dan dislokasi ekstremitas, cedera maksilo-fasial tanpa gangguan jalan nafas, serta gawat darurat psikologis).

Untuk melakukan evakuasi pada ibu hamil diperlukan teknik yang tepat dan aman untuk ibu dan calon bayinya. Berikut beberapa teknik evakuasi secara umum: ${ }^{12}$

\section{Firefighter's Carry}

Teknik evakuasi dengan satu penolong atau biasa disebut dengan teknik repling. Namun teknik ini dilakukan saat sudah dipastikan korban tidak mengalami patah tulang punggung karna akan memperparah keadaan.

\section{Pack-strap Carry}

Teknik ini digunakan ketika firefighter carry tidak aman digunakan, metode ini lebih disarankan untuk jarak jauh daripada cradle carry. Dapat dilakukan pada korban yang tidak sadar.

\section{Chair lift}

Mobilisasi dengan kursi bisa digunakan untuk korban sadar maupun tidak, tanpa cedera kepala/ spinal. Metode ini bagus untuk mobilisasi korban melalui tangga/ turunan/ naikan dengan dua penolong.

\section{Two-handed Seat Carry}

Metode ini digunakan untuk mobilisasi jarak jauh. Korban dapat sadar maupun tidak, tetapi tidak dapat berjalan atau menopang tubuh bagian atas.

\section{Hammock Carry}

Metode ini bisa digunakan oleh tiga penolong atau lebih. Anggota yang paling kuat berada di sisi dengan jumlah penolong yang paling sedikit (jika jumlah ganjil).

\section{Logroll}

Pada kasus cedera spinal, digunakan teknik logroll dengan tujuan memindahkan korban tanpa menggerakkan vertebra atau istilah lainnya adalah inline immobilisation (posisi leher dan batang badan harus segaris, amankan leher dengan neck collar atau yang sejenis (sandal bag), jika tidak tersedia dapat diamankan dengan dipegang). Selain untuk mempermudah proses memindahkan korban ke alat 
(karena alat yang menyesuaikan posisi korban), logroll juga digunakan untuk memeriksa bagian bawah tubuh korban. Minimal dilakukan oleh tiga penolong.

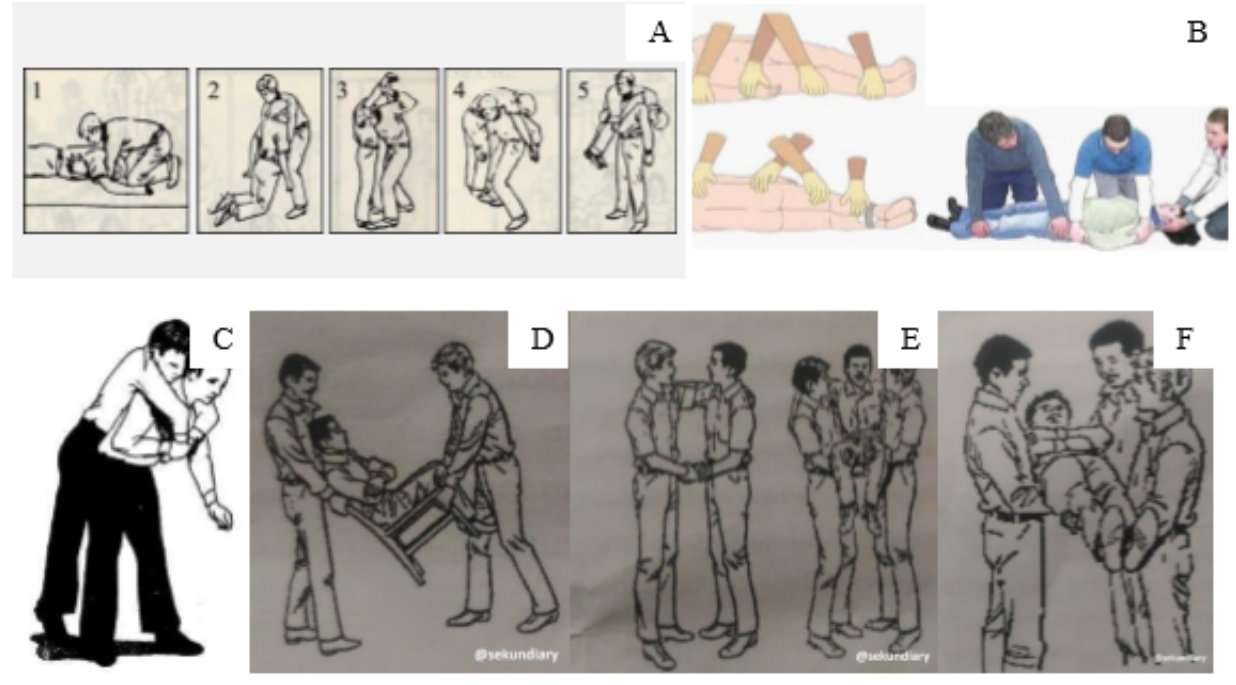

Gambar 1. Teknik evakuasi. A. Firefighter's Carry. B. Logroll. C. Pack-strap Carry. D. Chair lift. E. Two handed Seat Carry. F. Hammock Carry. ${ }^{12}$

Korban umum biasanya dievakuasi dalam posisi berbaring karena posisi inidapat membantu untuk monitor dan kontrol jalan napas. Namun, pada ibu hamil justru dapat menimbulkan aliran uterus berkurang dan tahanan darah di dalam ekstremitas bawah sehingga mempengaruhi cardiac output ibu. Untuk menghindari masalah tersebut, posisi terbaik adalah posisi miring dengan kedua lutut dilipat. Dengan posisi ini sabuk pengaman dapat dipasang dengan mudah, tetapi monitoring pernafasan tidak optimal. ${ }^{13}$

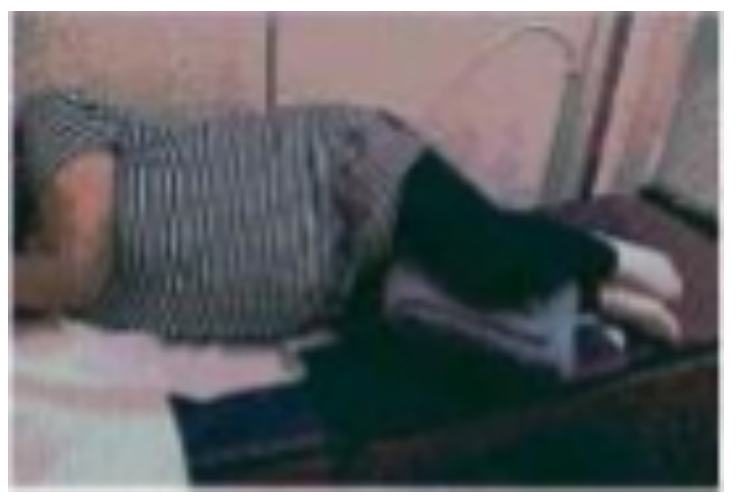

Gambar 2. Posisi evakuasi korban ibu hamil. ${ }^{13}$
Pada korban hamil dengan gangguan punggung tidak dapat dievakuasi dalam posisi miring, melainkan dengan cara berikut: ${ }^{13}$

1. Uterus ditekan dari arah kiri ke kanan korban. Walaupun tindakan ini efektif untuk memulihkan aliran darah jantung yang normal bagi korban maupun janin, tetapi tindakan ini memerlukan lebih dari satu orang penolong untuk menjaga uterus tetap di sisi kana korban.

2. Letakkan bantal kecil, selimut, atau handuk pada pinggang kiri korban. Elevasi setinggi 4 inchi untuk mengurangi tekanan uterus pada vena cava inferior.

Setelah evakuasi korban, langkah selanjutnya adalah pengobatan cedera. Ada banyak tantangan untuk kesehatan wanita dalam bencana. Semua aspek perawatan untuk wanita hamil (perawatan prenatal, intrapartum, dan postpartum) dapat 
dikompromikan. ${ }^{14}$ Opsi kontrasepsi dapat dikurangi. Kekerasan seksual dapat menyebabkan peningkatan penyakit dan cedera menular seksual. ${ }^{15}$ Apabila korban mengalami cedera dan fraktur diperlukan teknik balut bidai dengan imobilisasi. Korban dengan perdarahan yang masif diperlukan penanganan segera dengan resusitasi cairan.

Di Amerika Serikat, trauma obstetrik memperumit 6-7\% kehamilan. Trauma adalah penyebab utama non-obstetri dari morbiditas dan mortalitas ibu dan merupakan $46 \%$ kematian ibu. Karena perubahan fisiologis dan anatomi kehamilan, risiko trauma pada ibu dan janin meningkat dengan usia kehamilan. Perubahan anatomi kehamilan ini mengubah pola cedera. Peningkatan pembengkakan pembuluh panggul menyebabkan peningkatan risiko perdarahan retroperitoneal dan hematoma. Trauma abdominal tumpul dapat menyebabkan cedera pada kandung kemih, limpa, dan patah tulang panggul. Trauma tumpul juga dapat menyebabkan ruptur uterus perlambatan cepat, terutama di mana telah ada operasi caesar sebelumnya. Luka tusuk perut bagian atas dapat menyebabkan cedera usus yang lebih kompleks karena perpindahan isi perut bagian atas. ${ }^{15}$

Tingkat gangguan radang panggul (PID), gangguan menstruasi, dan penurunan kesuburan lebih tinggi setelah Gempa Wenchuan 2008. Dalam laporan lain yang menganalisis hasil kebidanan setelah bencana banjir di Kotlin Klodzki, Polandia 1997, untuk 47 wanita hamil yang terluka dalam kebuntingan kehamilan adalah 55,3\% dibandingkan dengan tidak ada kerugian dalam kelompok kontrol acak dari 100 wanita hamil pada tahun 1996. Bagi para korban banjir, kerugian terjadi karena meningkatnya kelahiran prematur, ketuban pecah dini, peningkatan aborsi yang terlewat, asfiksia lahir, dan retardasi pertumbuhan intrauterin. ${ }^{15}$

Selain menghadapi konstelasi cedera yang sama dari cedera ortopedi, infeksi, dan kerawanan pangan seperti pria, wanita juga memiliki risiko unik yang inheren berdasarkan peran sosial mereka dan kerentanan terhadap predator seksual. Risiko unik ini selama bencana termasuk kehilangan kehamilan, konsekuensi jangka panjang pada hasil kehamilan dan kesuburan masa depan, kekerasan seksual, dan penyakit menular seksual. ${ }^{15}$

Persalinan ketika proses evakuasi lebih sulit ditangani dan lebih berbahaya. Hal ini harus didampingi oleh petugas medis yang kompeten sampai fasilitas kesehatan yang dituju. Saat evakuasi pun dapat menyebabkan perburukan kondisi pada korban ibu hamil, seperti perdarahan, syok, Disseminated Intravascular Coagulation (DIC), dan eklampsia. ${ }^{14,15}$

1. Perdarahan yang sering terjadi disebabkan adanya solusio plasenta. Hal ini dapat terjadi tanpa manifestasi perdarahan pervaginam. Dalam beberapa menit korban dapat kehilangan setengah volume darahnya dan menyebabkan syok yang apabila tidak segera ditangani dapat menyebabkan kematian. Untuk menghindari korban jatuh dalam kondisi syok, harus segera dilakukan pemasangan IV (intravena) line.

2. Syok biasanya merupakan akibat dari perdarahan. Ha ini biasanya dapat diatasi dengan baik, tidak menunjukkan gejala/sindrom pre-syok, kecuali terjadi kolaps pebuluh darah yang mendadak.

3. DIC biasanya terjadi pada ibu hamil dengan pre-eklampsi berat, sindrom HELLP, dan perdarahan intrapartum. 
Hal ini dapat muncul tiba-tiba dan dapat mengakibatkan kematian.

4. Peningkatan tekanan darah ringan pada wanita hamil (pre-eklampsia) dapat berubah dengan cepat menjadi preeklampsia berat dan eklampsia (kejang). Wanita hamil denganpreeklampsia yang akan dievakuasi harus dilakukan pengawasan terhadap kenaikan tekanan darah dan tersedia obat serta alat penanganan eklampsia.

Beberapa hari pasca bencana pun dapat timbul kasus baru, diantaranya adalah kekurangan makanan. American College of Obstetricians dan Gynecologists (ACOG) mencatat bahwa kurangnya sumber daya termasuk makanan, air, dan tempat tinggal setelah bencana berdampak buruk pada kehamilan dan hasil kehamilan. ${ }^{15}$ Biasanya pada saat bencana, gizi pada ibu hamil dan menyusui tidak diperhatikan. Padahal pada Ibu hamil dan menyusui memerlukan tambahan zat gizi. Ibu hamil perlu penambahan energi 300 Kal dan Protein 17 gram, sedangkan ibu menyusui perlu tambahan Energi $500 \mathrm{Kal}$ dan Protein 17 gram. Suplementasi vitamin dan mineral untuk ibu hamil adalah Fe 1 tablet setiap hari. Khusus ibu nifas (0-42 hari) diberikan 2 kapsul vitamin A dosis 200.000 IU, yaitu 1 kapsul pada hari pertama, dan 1 kapsul pada hari berikutnya (selang waktu minimal 24 jam). Pemberian vitamin dan mineral dilakukan oleh petugas kesehatan. ${ }^{16,17}$

Selain masalah gizi, kesehatan mental pada ibu hamil seperti depresi dan kecemasan sangat umum terjadi pasca bencana. Hubungan antara masalah kesehatan mental dan kesehatan ibu adalah yang utama karena mereka secara langsung atau tidak langsung meningkatkan morbiditas dan mortalitas ibu, serta gangguan tumbuh kembang janin. ${ }^{18}$ Studi sebelumnya mengungkapkan bahwa kehadiran tingkat stres yang tinggi selama kehamilan dapat dikaitkan dengan hasil kelahiran yang buruk setelah bencana alam. Namun, karena bencana menyebabkan terbatasnya akses ke perawatan prenatal yang tepat, layanan persalinan yang aman, dan metode kontrasepsi. Satu studi menunjukkan hubungan yang signifikan antara PTSD (Posttraumatic stres disaster) dan kesehatan reproduksi wanita. ${ }^{19}$

Sementara penelitian lain menyimpulkan bahwa wanita dengan PTSD adalah kelompok berisiko tinggi untuk komplikasi kehamilan. ${ }^{18}$

Menurut WHO, serangkaian intervensi berbasis masyarakat telah terbukti bermanfaat dan efektif untuk wanita dengan masalah kesehatan mental. Misalnya, penyedia layanan kesehatan yang bekerja dalam layanan kesehatan seksual dan reproduksi dan merawat wanita hamil dapat dilatih untuk mengenali gejala dan tanda yang menunjukkan masalah kesehatan mental dan memberikan konseling kepada wanita tentang stres serta memberikan dukungan psikologis yang efektif dan intervensi lain. . Sebagian kecil wanita dengan gangguan fungsi berat sehari-hari akan membutuhkan dukungan spesialis dan resep obat-obatan psikotropika. ${ }^{17,20}$

Mengenai pemberian informasi, Juul Gouweloos dkk. menyarankan pihak berwenang untuk menginformasikan tentang risiko pajanan, tanda-tanda pajanan (misalnya, lokasi atau demam alih-alih peningkatan denyut jantung, atau gejala fisik lain yang juga disebabkan oleh kecemasan), tindakan melindungi diri (misalnya kepatuhan terhadap saran untuk memakai pakaian pelindung), tindakan berbahaya (misalnya mencari orang yang 
dicintai di daerah radiasi tinggi), karantina dan isolasi, strategi dekontaminasi, strategi vaksinasi dan distribusi obatobatan. ${ }^{7,21}$

Bentuk dukungan yang orang butuhkan adalah pertama dukungan praktis, kedua adalah berbicara atau tidak atau berbicara dengan orang-orang dari jaringan sosial mereka sendiri; tenaga profesional jarang berpengaruh. Berbagai rekomendasi untuk memfasilitasi dukungan diberikan. Pada awalnya, berkumpul dengan keluarga. Kedua, dalam kasus serangan teroris, pihak berwenang mungkin ingin memblokir ponsel. Karena orang menjadi lebih gelisah dan kurang tangguh ketika mereka tidak dapat mencapai orang yang mereka cintai, mereka akan enggan untuk diterapkan kebijakan ini dan mencari cara untuk mencegah blokade ini. Ketiga, dukungan praktis untuk kembali ke keadaan normal sehubungan dengan perumahan permanen yang layak, sekolah dan layanan masyarakat sangat penting untuk mengurangi risiko dampak psikologis jangka panjang pada anak-anak dan keluarga. Keempat, perhatian harus diberikan pada orang tua yang fokus mencari keluarganya. ${ }^{7,22}$

Wanita yang tinggal di daerah terkena dampak bencana berisiko lebih besar untuk tidak atau lebih pendek lamanya menyusui dibandingkan dengan wanita pada umumnya. Maka dari itu dukungan menyusui untuk ibu menyusui sangat diperlukan karena manfaat ASI (Air Susu Ibu) sangat diperlukan bagi bayi. ASI dapat berfungsi sebagai proteksi pertama dari penyakit-penyakit yang dapat timbul pasca bencana. ${ }^{23}$

\section{KESIMPULAN}

Korban ibu hamil pasca bencana termasuk dalam kategori triage warna merah (pasien gawat darurat) yang membutuhkan pertolongan segera dan tepat. Manajemen penyelamatan ibu hamil pasca bencana meliputi evakuasi, penanganan cedera, kontrol gizi dan psikis. Evakuasi paling tepat untuk ibu hamil adalah posisi miring dengan lutut dilipat. Jika terdapat cedera punggung lakukan usaha agar vena cava inferior tidak tertindih uterus. Cedera yang perlu diwaspadai adalah dapat terjadinya perdarahan, syok, DIC, dan eklamsi. Pemulihan gizi dan psikis ibu hamil juga sangat penting untuk mencegah hal-hal yang tidak diinginkan pada ibu maupun janin.

\section{REFERENSI}

1. BNPB. Rencana Nasional Penanggulangan Bencana 2015-2019. Jakarta: BNPB. 2014

2. Undang-Undang Repubik Indonesia Nomor 24 Tahun 2007 Tentang Penangguangan Bencana

3. Setiawan, Riyan. "BNPB: $60 \%$ Sampai 70\% Korban Bencana adalah Perempuan dan Anak" (onine), (https://irto.id/bnpb-60-sampai70korban-bencana-adalah-perempuandan-anakdgod, diakses tanggal 3 Juli 2019). 2019

4. Hibino, Y., dkk. "Health impact of disasterrelated stress on pregnant women living in the affected area of the Noto Peninsula earthquake in Japan". Psychiatry and Clinical Neurosciences, 2009; 63: 107-115.

5. Yamamoto, T., \& al., e.’'Investigative Research Projects Related to The Yohoku Earthquake (The Great East Japan Earthquake) Conducted in Fukushima". Fukushima J. Med. Sci. 2015; Vol. 61(2): 155-159.

6. Martiany, D. "Penanganan Khusus Pengungsi Perempuan Pada Masa Tanggap Darurat Bencana 
SULTENG". Puslit, 2018; Vol X(19), 13-18.

7. Kementerian Kesehatan RI. INFODATIN: Situasi Kesehatan Ibu. Jakarta Selatan: Pusat Data dan Informasi Kementerian Kesehatan RI. 2014

8. Kementerian Kesehatan. Profil Kesehatan Indonesia 2012. Jakarta: Pusat Data dan Informasi Kementerian Kesehatan RI. 2013

9. Prawirohardjo S. Buku Acuan Nasional Pelayanan Kesehatan Maternal dan Neonatal. Jakarta: Yayasan Bina Pustaka Sarwono Prawirohardjo. 2008.

10. Gouweloos, Juul, dkk. "Psychosocial Care to Affected Citizens and Communities in Case of CBRN Incidents: Systematic Review". Jurnal Elsevier, 2014; 4-6.

11. Kushayati, N. "Analisis Metode Triage Prehospital pada Insiden Korban Masal (Mass Casualty Incident)". UNY Journal, 2014; 1-9.

12. Sastrawan, I. G., dkk. Buku Kurikulum Pendidikan dan Latihan PTBMMKI. 2018

13. Depkes RI. Pedoman Penanganan Evakuasi Medik. Jakarta: Direktorat Bina Pelayanan Medik Dasar. 2009

14. Londok, dkk. "Karakteristik Perdarahan Antepartum dan Perdarahan Postpartum". e-Biomedic, 2013;1(1): 614-620.

15. Goodman, A. "In The Aftermath of Disasters: The Impact on Women's Health". iMedPub Journals , 2016; 2(6):1-5.

16. Pakaya, Rustam S., et all. Pedoman Teknis Penanggulangan Krisis Kesehatan Akibat Bencana. Jakarta: DepKesRI. 2007

17. Mudjiharto,et al. Pedoman Teknis Penanggulangan Krisis Kesehatan Akibat Bencana. Jakarta: Depkes RI. 2011

18. World Health Organization. Millennium Development Goal 5 Improving Maternal Mental Health.
Geneva: Department of Mental Health and Substance Abuse World Health Organization. 2008

19. Farooqui, Mudassir, dkk. "Posttraumatic Stress Disorder: a Serious Post-Earthquake Complication". Jurnal Trends Psychiatry Psychother, 2017; 39(2):1 35-143.

20. Sugiantono, Anung, dkk. Buku Pedoman Paket Pelayanan Awal Minimum (PPAM), Kesehatan Reproduksi pada Krisis Kesehatan. Jakarta: Kemenkes RI. 2014

21. Harville, E., dkk. "Disasters and Perinatal Health: A Systematic Review". Obstet Gynecol Surv, 2010; 65(11): 713-728.

22. Kemal, A., dkk. Buku Saku Pelayanan Kesehatan Ibu di Fasilitas Kesehatan Dasar dan Rujukan. Jakarta: 2013;Kemenkes RI.

23. Setyarini, D. I., \& Suprapti. Asuhan Kebidanan Kegawatdaruratan Maternal dan Neonatal. Jakarta: 2016; Kemenkes RI. 